\title{
ОСОБЛИВОСТІ ОРГАНІЗАЦЇ САМОСТІЙНОЇ РОБОТИ СТУДЕНТІВ МЕДИЧНОГО КОЛЕДЖУ
}

\author{
М. А. Давидчук
}

\section{Криворізький медичний коледж}

\begin{abstract}
Медична освіта будь-якого рівня увиразнюється своєю неповторною специфікою, що вимагає упровадження власних форм, методів, засобів розвитку клінічного мислення, становлення професійних та прагматичних позицій, оптимізації міжособистісних стосунків. У пропонованій публікації автор розглянув основні види і форми самостійної роботи студентів медичного коледжу як дефініції, що забезпечує подальший особистісний розвиток й удосконалення; виокремив прийоми активізації самостійної роботи з погляду підвищення ефективності освітнього процесу.
\end{abstract}

\section{THE FEATURES OF ORGANISATION OF STUDENTS’ INDEPENDENT WORK IN MEDICAL COLLEGE}

\author{
M. A. Davydchuk
}

Kryvyi Rih Medical College

\begin{abstract}
Medical education of any level is manifested by its unique characteristics, which requires the introduction of their own forms, methods, means of development of clinical thinking, formation of professional and pragmatic positions, optimization of interpersonal relations. In the proposed publication, the author considered the main types and forms of students `independent work in medical college as a definition that provides further personal development and improvement; methods of promotion of independent work in terms of increasing the efficiency of the educational process are selected.
\end{abstract}

Вступ. Стрімкі сучасні реформувальні процеси охопили усі галузі українського суспільства. Медична освіта не стала винятком. Особлива увага звертається до молодих фахівців, здатних швидко обробляти масиви змінювальної інформації, критично аналізувати, легко мобілізуватися, а відтак, бути конкурентоспроможним на ринку праці. Тож, під час навчання у вищому навчальному закладі, значення набуває самостійна робота студентів, правильна організація якої забезпечить становлення таких особистісних якостей, як саморозвиток, самовдосконалення, відповідальність за якість власних знань. Не останню роль відіграє й значне зменшення навчальними планами часу, відведеного на теоретичні заняття. Тож, в умовах аудиторії можуть розглядатись та засвоюватись лише ті навчальні фрейми, які, з огляду на обсяг, наявність суперечливих моментів, неоднозначність трактування або необхідність безпосереднього контролю викладача не можуть бути засвоєні самостійно. У такому ракурсі, значення набувають зміст, мета, види, форми, методи, обсяг, з'ясування часових витрат, формулювання завдань та прийоми контролю.

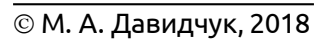

Висвітлені позиції підтверджують беззаперечність проблемності питання, яке неодноразово порушувалось провідними дидактами й викладачами.

У педагогіці виокремлюють різні підходи до трактування поняття «самостійна робота студентів». Найбільш поширеними та прийнятними для нашого пошуку є такі:

- дидактична форма навчання, що є системою організації педагогічних умов, які забезпечують управління навчальною діяльністю тих, хто навчається, й організовується викладачем; підсистему системи навчання, у якій через власні засоби й у специфічних умовах можуть розв'язуватися подібні завдання, як і в усій системі пізнавальної загалом, чи в підсистемі несамостійної, роботи (О. Малихін) [1];

- спланована організаційно й методично скоординована (доаудиторна, аудиторна, позааудиторна) пізнавальна діяльність студентів для оволодіння фаховими компетентностями, що реалізується без імперативних рекомендацій викладача, натомість в умовах систематичного педагогічного керівництва 3 можливістю вибору кожним студентом індивідуальної освітньої траєкторії (І. Нагрибельна) [2]; 
- важливий компонент освітнього процесу, що передбачає інтеграцію різних видів індивідуальної та колективної діяльності, яка здійснюється як під час аудиторних, позааудиторних занять без участі викладача, так і під його безпосереднім керівництвом (Н. Чорний) [3];

- різні види індивідуальної та колективної діяльності студентів, яка здійснюється на аудиторному та позааудиторному заняттях, чи вдома за завданням без участі викладача безпосередньо (І. Шимко) [4].

Ураховуючи специфіку навчання у медичному коледжі та особливості майбутньої професійної діяльності поняття «самостійна робота студентів медичного коледжу» витлумачуємо як активний вид пізнавальної діяльності, що характеризується самостійним пошуком, аналізом, систематизацією та усвідомленням суб'єктивно нових знань; формуванням та екстраполяцією професійно значущих умінь на вимоги практичної медицини; самоконтролем; саморозвитком.

Сучасне суспільство, динамічні зміни на ринку праці, поява нового специфічного моніторингового, лабораторного або маніпуляційного обладнання вимагають від фахівців медицини швидкого реагування на професійні ризики, виокремлення та систематизація за рівнем пріоритетності проблем пацієнта, визначення валідної тактики їх розв'язання, упровадження, окрім терапевтичних, профілактичних та реабілітаційних заходів, спрямованих на збереження здоров'я населення.

Задля розв'язання означеної проблеми, викладачами циклу «Основи медсестринства» Криворізького медичного коледжу, в результаті узагальнення та систематизації досвіду передових дидактів, власних напрацювань із урахуванням специфіки медсестринської освіти виокремлено певні шляхи оптимізації означеного феномена. Поряд із цим виявилася низка дискусійних питань, що потребують певного уточнення.

Основна частина. Переважно самостійна робота реалізується студентами в умовах аудиторій та поза ними. Вважаємо, що забезпечення якісного виконання завдань можливе за дотримання таких вимог: 1) на самостійне опанування виносять лише ті теми, які студент може засвоїти без сторонньої допомоги, із унеможливленням помилкового розуміння основних позицій; 2) у пропонованих завданнях враховані індивідуальні можливості й рівень попередньої підготовки, що забезпечить активні особистісні навчальні дії; 3) виконання такої роботи потребує чіткої регламентації часу, адекватної до складності завдань.
Посилаючись на висловлені тези, ми зробили спробу проаналізувати більш поширені форми організації самостійної роботи студентів у медичному коледжі. По-перше, навчальною програмою та дидактичними вимогами передбачено теоретичну підготовку студентів. Тут особливу увагу приділяють лабораторним, доклінічним або клінічним практичним заняттям. Звичайно, опанування необхідним комплексом маніпуляційних, аускультативних або перкусійних умінь і навичок не можливе без досконалого вивчення алгоритмів дій. Інтеграції знань суміжних дисциплін потребує й процес диференціації анамнестичних даних задля встановлення медсестринського діагнозу пацієнту із урахуванням індивідуальних особливостей (вік, стать, життєві анамнестичні дані, різний ступінь прояву основних та супровідних симптомів). Проте абсолютно упускається підготовка до теоретичних занять. Адже, за умов теперішнього розподілу навчальних годин, лекції набули, переважно, оглядового характеру. Обізнаність студентів із тих чи інших питань конкретної теми дозволяє впроваджувати проектувальні, дискусійні, проблемні дидактичні методи, що забезпечують якісну теоретичну підготовку та реалізацію знаннєвого освітнього компонента.

По-друге, особливого значення набуває питання формування практичних умінь і навичок. Вважаємо доцільним розділити цей процес на два складники. Перший компонент повинен реалізовуватись у кабінетах доклінічної підготовки. Він передбачає попередню неодноразову демонстрацію тих чи інших маніпуляційних технік викладачем у супроводі синхронного озвучування алгоритму. У подальшому, студенти, під безпосереднім контролем викладача, повторюють комплекс дій, проявляючи репродуктивні уміння. Таким чином, упроваджуються ланки самота взаємоконтролю, своєчасна професійна корекція можливих помилок. Другий компонент, за наявності відповідних умов (кабінети тренінгу), вбиратиме самостійне опанування професійних умінь та трансформацію їх у навички. Цьому процесу сприятиме і власне клінічна практика, яка передбачає роботу в лікувально-профілактичних установах при безпосередньому контакті із пацієнтами та співпрацею із співробітниками лікарень.

По-третє, підготовка до розв'язання тестових завдань. Такий вид роботи можна цілком залишити на самостійне опанування. Час, відведений на пошук правильної відповіді із запропонованих варіантів, лімітовано. Процес розв'язання завдань потребує тео- 
ретичної підготовки та звіряння із еталонами. Узгодити тривалість власної роботи із часом, відведеним на виконання завдань, можна працюючи у комп'ютерних класах за спеціальною програмою «Колоквіум», або у домашніх умовах з іншими альтернативними системами. Отже, необхідності в присутності викладача, за таких умов немає, але й не можна залишити без контролю. Оскільки тестові випробування упроваджено на різних етапах освітнього процесу, в тому числі й під час складання ліцензійних іспитів «КРОК М».

По-четверте, реферування навчального матеріалу за запропонованою темою. Доречність такої роботи, на наш погляд, визначається метою завдання та рівнем попередньої підготовки студентів. Реферування буде доцільним, якщо передбачатиме формування таких умінь, як робота з різними інформаційними джерелами, аналіз наукових публікацій, систематизація отриманого матеріалу, узагальнення та формулювання висновків, визначення можливих шляхів подальших досліджень. В інших випадках, все зводитиметься до банального плагіату Інтернет-ресурсів або механічного переписування у студентів, які виявляють більшу самостійну активність або навчаються на старших курсах. Ураховуючи низький рівень підготовки майбутніх медиків до самостійної діяльності, альтернативний шлях розв'язання проблеми вбачаємо у складанні коротких конспектів, фреймів, структурно-логічних схем, інтелектуальних карт до теми заняття. Така робота паралельно значно полегшить процес опанування суб'єктивно нових теоретичних знань.

Такі форми самостійної роботи, як дослідження, експериментування, опрацювання групових або індивідуальних проектів застосовують вкрай рідко i, переважно, з-поміж студентів навчальних гуртів.

Якщо мету самостійної роботи студентів убачати у формуванні здатності особистості усвідомлено та без сторонньої допомоги опрацьовувати певні масиви інформації загального та професійного характеру, що забезпечить процеси саморозвитку, самоосвіти

\section{СПИСОК ЛІТЕРАТУРИ}

1. Малихін О. В. Організація самостійної навчальної діяльності студентів вищих педагогічних закладів : теоретико-методологічний аспект : [монографія] / О. В. Малихін. - Кривий Ріг : Видавничий дім, 2009. - 307 с.

2. Нагрибельна І. А. Самостійна робота в системі підготовки майбутніх учителів до навчання української мови в початкових класах : дис. ... д-ра пед. наук : 13.00.02 / Інна Анатоліївна Нагрибельна. - Херсон, 2016. - 483 с. й самовдосконалення, то, у якості ефективних, пропонуємо такі прийоми активізації:

1) переконливе забезпечення усвідомлення необхідності опанування тих чи інших професійних компетенцій;

2) проблемне викладання навчального матеріалу із відтворенням типових шляхів розв'язання визначених завдань;

3) впровадження активних дидактичних методів (дискусії, робота в різних за кількісним складом групах, інсценування клінічних ситуацій, проектування, дослідництво);

4) обов'язкова демонстрація маніпуляцій викладачем відповідно до алгоритму дій, із наступною покроковою курацією задля унеможливлення формування помилкових дій;

5) створення та впровадження методичних матеріалів організації самостійної роботи, що міститимуть теоретичний матеріал, методичні вказівки, завдання різного рівня складності та критерії оцінювання;

6) організація моніторингового контролю на всіх етапах виконання самостійної роботи.

Висновки. Наведені позиції дозволяють стверджувати про те, що самостійна робота сприяє поглибленню та розширенню знань, формуванню позитивної навчальної мотивації, особливо до професійного компонента, оволодінню та розвитку пізнавальних прийомів. Основні вимоги, що висувають до завдань самостійного опрацювання, формулюємо так: реальність виконання; можливість самоконтролю; попередня демонстрація практичних навичок; дотримання принципів індивідуальності та особистісної зорієнтованості навчання.

Цілеспрямована організація самостійної роботи студентів дозволить сформувати ініціативних, здатних до логічного мислення фахівців медицини європейської формації, що усвідомлюють суспільну значущість обраної професії та відповідають соціально-економічним та культурним вимогам країни.

3. Чорній Н. В. Самостійна робота студентів як складова частина у підготовці спеціаліста в умовах кредитномодульної системи навчання / Н. В. Чорній // Медична освіта. - 2014. - № 4. - С. 132-134.

4. Шимко І. М. Дидактичні умови організації самостійної навчальної роботи студентів вищих навчальних закладів: дис. ... канд. пед. наук : 13.00.04 / Ія Миколаївна Шимко. Кривий Ріг, 2003. - 196 с. 